\title{
Exoproduction and Biochemical Characterization of a Novel Thermophilic Serine Protease From Ornithinibacillus Caprae L9T With Hide-dehairing Activity
}

\section{Xiaoguang Li}

Sichuan University

Qian Zhang

Sichuan University

Longzhan Gan

Sichuan University

Guangyang Jiang

Sichuan University

Yongqiang Tian ( $\nabla$ yqtian@scu.edu.cn )

Sichuan University https://orcid.org/0000-0001-5729-209X

Bi Shi

Sichuan University

\section{Research Article}

Keywords: Ornithinibacillus caprae, Response surface methodology, Serine protease, Dehairing

Posted Date: June 7th, 2021

DOl: https://doi.org/10.21203/rs.3.rs-573853/v1

License: (c) (i) This work is licensed under a Creative Commons Attribution 4.0 International License. Read Full License

Version of Record: A version of this preprint was published at Journal of Microbiology and Biotechnology on November 20th, 2021. See the published version at https://doi.org/10.4014/jmb.2108.08037. 


\section{Abstract}

BLAST, basic local alignment search tool; BBD, Box-Behnken design; BSA, bovine serum albumin; CGMCC, China General Microbiological Culture Collection Center; DMSO, dimethyl sulfoxide; DTT, dithiothreitol; EDTA, ethylene-diamine-tetraacetic acid; EGTA, ethylene glycol-bis ( $\beta$-aminoethyl ether)-N,N,N',N'tetraacetic acid; GBDP, genome blast distance phylogeny; HE, hematoxylin and eosin; KCTC, Korean Collection for Type Cultures; LC-MS/MS, liquid chromatography-tandem mass spectrometry; LB, LuriaBertani; $\beta$-ME, $\beta$-mercaptoethanol; NR, non-redundant protein database; PMSF, phenylmethylsulfonyl fluoride; RSM, response surface methodology; SDS-PAGE, sodium dodecyl sulfate-polyacrylamide gel electrophoresis; SD, standard deviation; TCA, trichloroacetic acid; TSB, tryptic soytone broth; TYGS, type strain genome server; UV-Vis, ultraviolet-visible.

\section{Introduction}

China, one of the major leather-producing countries, is well known for its most active and potential leather trading markets worldwide. According to the China Leather Industry Association data, around 529 million square meters of genuine leather was produced in China in 2019. The leather industry mainly uses hides and skins, the livestock by-products, as the raw materials for processing. Leather processing involves many physical and chemical treatments such as soaking, dehairing, bating and tanning (Ward 2011). The dehairing of skin/hide is considered as the most polluting process (Kandasamy et al. 2012). The traditional hair-removal methods require the use of several chemical depilatory agents, such as sodium sulfide, sodium bisulfide and calcium chloride (Ockerman and Basu 2014), which contribute to environmental pollutions, including the generation of noxious gases and solid wastes (Kanagaraj et al. 2015; Thanikaivelan et al. 2004). Therefore, the introduction of more eco-friendly methods is highly desirable. In this regard, microbial proteases could fill this niche (Paul et al. 2016).

Enzymatic dehairing, which has been proved to be the most cost-effective and eco-friendly process, exerts tremendous potential in obtaining high-quality leather (Wang et al. 2009). This phenomenon has increased the attention toward the exploitation of enzyme-producing microorganisms (Barzkar 2020). So far, a variety of extracellular proteases have been reported and characterized from different microorganisms, including fungi like Paecilomyces marquandii (Gradisar et al. 2005), and bacteria, such as Bacillus subtilis (Dettmer et al. 2013), Lactobacillus curvatus (Sun et al. 2019), Nocardiopsis dassonvillei (Sharma et al. 2020) and Streptomyces koyangensis (Ben Elhoul et al. 2015). Interestingly, most of the reported extracellular proteases are serine proteases (Brandelli 2007; Jaouadi et al. 2013), while a few belong to metalloproteases (Wang et al. 2008; Chandrasekaran et al. 2016). As a member of the proteolytic enzyme family, serine proteases exert a wide range of biotechnological applications, including skin dehairing (Jaouadi et al. 2013), feather degradation (Jagadeesan et al. 2020), stain washing (Haddar et al. 2009), food production (Kostyleva et al. 2016), silk degumming and sericin degrading (Suwannaphan et al. 2017). Of the reported proteases to date, the extracellular serine proteases were preponderantly secreted by Bacillus strains. However, little attention has been paid to the rare strains, especially the species of Ornithinibacillus. 
Ornithinibacillus species are generally Gram-stain-positive, aerobic, rod-shaped and moderately halophilic bacteria from the family Bacillaceae (Li et al. 2020). Over the past decades, a total of 12 strains have been isolated and placed in the genus Ornithinibacillus (Parte et al. 2020). Despite these studies, no protease from Ornithinibacillus strains has been reported so far. Therefore, further research on the proteases secreted by Ornithinibacillus species is highly necessitated to expand the existing industrial enzyme toolbox and achieve potential applications. In the previous study, an extracellular proteaseproducing bacterium, Ornithinibacillus sp. $L 9^{\top}$, was isolated from a goatskin and scientifically classified as Ornithinibacillus caprae ( $\mathrm{Li}$ et al. 2020). In addition, strain $\mathrm{L} 9^{\top}$ could produce a transparent hydrolysis ring on milk plates supplemented with $100 \mathrm{~g} / \mathrm{L} \mathrm{NaCl}$. Herein, the extended research was set out to enhance the extracellular protease production from 0 . caprae $L 9^{\top}$ by optimizing the medium components and fermentation conditions. Simultaneously, the crude enzyme was investigated for the biochemical and molecular characteristics, and used as a biocatalyst for dehairing hides to provide a theoretical foundation for further application in the leather industry.

\section{Materials And Methods}

\section{Microorganism and reagents}

The moderate halobacterium 0 . caprae $L 9^{\top}$ was isolated from a goat hide obtained from a local farm in Chengdu, south-west China (Li et al. 2020). The bacterium was deposited in the laboratory of industrial biotechnology, the Korean Collection for Type Cultures (KCTC, Korea) and China General Microbiological Culture Collection Center (CGMCC, China) with accession number L9, KCTC 43176 and CGMCC 1.17659, respectively.

Unless specified, all the chemical reagents used in this experiment were of analytical. Casein, gelatin and collagen were purchased from Sangon Biotech (China). Keratin from wool, azocasein, bovine serum albumin (BSA), Folin \& Ciocalteu's phenol reagent and protein marker were obtained from Tokyo Chemical Industry Co., Ltd. (Japan), Sigma-Aldrich (American), BioFroxx (Germany), Solarbio (China) and Takara (Japan), respectively. All other tested chemicals, surfactants, organic solvents and media components were obtained from several commercial companies.

\section{Genomic analysis}

The genome sequence data has been uploaded to the type strain genome server (TYGS) (Meier-Kolthoff and Goker 2019) to determine the genome-based phylogeny of strain $L 9^{\top}$. Meanwhile, the DNA sequences were performed BLASTX search against the non-redundant protein database (NR) (Li et al. 2002) in the National Center for Biotechnology Information to assess the variety of genes in the $L 9^{\top}$ strain.

\section{Inoculum preparation and protease production}

The pure culture of bacterium $L 9^{\top}$ was precultured in LB broth medium supplemented with $100 \mathrm{~g} / \mathrm{L} \mathrm{NaCl}$ [used to inoculate $(2 \%, v / v)$ all fermentation medium for protease production]. After the fermentation was 
completed, the crude enzyme extract was obtained by removing the cell biomass through high-speed centrifugation for $5 \mathrm{~min}$ at $4{ }^{\circ} \mathrm{C}$, and stored at $0^{\circ} \mathrm{C}$ for further analyses.

\section{Determination of protease activity}

Protease activity was measured using casein as a substrate according to the national standardization administration commission GB/T 23527-2009 with minor modifications. The reaction was performed in an Eppendorf tube with a total volume of $2 \mathrm{~mL}$, containing $0.2 \mathrm{~mL}$ of appropriately diluted enzyme solution and $0.2 \mathrm{~mL}$ casein $(20 \mathrm{~g} / \mathrm{L})$ dissolved in Tris- $\mathrm{HCl}(\mathrm{pH} 7)$. The mixed components were incubated at $70{ }^{\circ} \mathrm{C}$ for $10 \mathrm{~min}$, and the reaction was stopped using $0.4 \mathrm{~mL}$ of $65.4 \mathrm{~g} / \mathrm{L}$ trichloroacetic acid (TCA). After shaking evenly, the unreacted casein precipitate was removed by centrifugation at $12000 \mathrm{rpm}$ for 5 min. Later, $0.4 \mathrm{~mL}$ of clear supernatant was mixed with $2 \mathrm{~mL}$ of $42.4 \mathrm{~g} / \mathrm{L} \mathrm{Na}_{2} \mathrm{CO}_{3}$ and $0.4 \mathrm{~mL}$ of $1 \mathrm{M}$ Folin $\&$ Ciocalteu's phenol reagent. The mixture was incubated for $20 \mathrm{~min}$ at $40^{\circ} \mathrm{C}$ and cooled under running water. Then the absorbance was monitored at $680 \mathrm{~nm}$ against the control using a UV-Vis spectrophotometer (UV-1100, Mapada, China). The assay was conducted in triplicate, and a control was run in parallel in which the substrate was added after the addition of TCA. One unit of protease activity $(\mathrm{U} / \mathrm{mL})$ was designated as the amount of enzyme required to release $1 \mu \mathrm{g}$ of tyrosine per minute under specified assay conditions.

\section{Optimization of protease production by strain $\mathrm{L}^{\top}$}

The effect of fermentation process variables on the extracellular protease derived from 0 . caprae $L 9^{\top}$ was investigated using the one-variable-at-a-time approach and response surface methodology (RSM). Three independent variables ( $\mathrm{C}$ source, $\mathrm{N}$ source and initial $\mathrm{pH}$ ), with the most significant effect on protease production, were selected. Then, the optimum levels and interaction of these three factors for enhancing the protease production were evaluated by RSM using Box-Behnken design (BBD). Each factor was investigated at three different levels: low (-1), central (0) and high (1) (Table S1). The experimental matrix was designed using DesignExpert 8.0.6 (Stat-Ease Inc., Minneapolis, USA), consisting of 17 experimental runs in which 5 runs were repeated at the central level (Table S2). The proteolytic activity $(\mathrm{U} / \mathrm{mL})$ was recorded as a response, and the response surface model was constructed and analyzed.

\section{SDS-PAGE, zymography and peptide identification}

Sodium dodecyl sulfate-polyacrylamide gel electrophoresis (SDS-PAGE) of the crude enzyme was performed using a PAGE gel preparation kit (BaiHe, China) according to the method described by Laemmli (Laemmli 1970) under denaturing conditions.

The caseinolytic activity was confirmed by zymography analysis according to the method described by Garciacarreno et al. (1993) with minor modifications. The sample was mixed with an equal volume of $2 \times$ SDS non-reducing loading buffer, and then electrophoresed. The gel was soaked twice in $50 \mathrm{mM}$ Tris$\mathrm{HCl} \mathrm{pH} 7$ buffer containing $2.5 \%(\mathrm{v} / \mathrm{v})$ Triton X-100 with agitation to remove SDS. Subsequently, the gel was submerged in Tris-HCl buffer for 40 min to remove Triton X-100. Later, the hydrolysis reaction 
occurred inside the gel during incubation at $40^{\circ} \mathrm{C}$ for $12 \mathrm{~h}$ in Tris- $\mathrm{HCl}$ containing $10 \mathrm{~g} / \mathrm{L}$ casein. At last, the gel was stained with the dye solution composed of $25 \%(\mathrm{v} / \mathrm{v})$ ethanol, $8 \%(\mathrm{v} / \mathrm{v})$ acetic acid and $1 \mathrm{~g} / \mathrm{L}$ Coomassie Brilliant Blue R-250 for $12 \mathrm{~h}$. The appearance of a white band on the dark blue background indicated the presence of protease activity.

Later, the white band was extracted from the gel, and subjected to reduction, alkylation, trypsin digestion and desalination. The obtained peptide mixture was analyzed using liquid chromatography-tandem mass spectrometry (LC-MS/MS) coupled with a TripleTOF 5600 system at Sangon Biotech. All mass spectra were acquired in the $\mathrm{m} / \mathrm{z}$ 350-1350 mass range, and the obtained peptide sequences were searched against the GenBank database using ProteinPilot software (version 4.5) with the Paragon algorithm.

\section{Protease biochemical characterization}

Temperature optima and thermal stability

The optimum temperature of protease activity was evaluated at $30-80^{\circ} \mathrm{C}$ for 10 min using Tris- $\mathrm{HCl}$

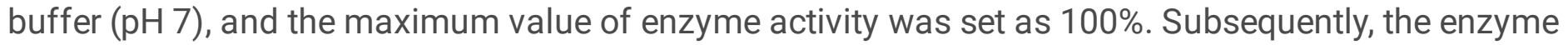
solution was pre-incubated at $30-80^{\circ} \mathrm{C}$ for $1 \mathrm{~h}$, and the residual enzymatic activities were measured at the optimum temperature to evaluate the thermal stability of the protease. All the analyses were conducted in triplicate.

pH optima and stability

For optimum $\mathrm{pH}$ assay, the crude enzyme solution was diluted in the following buffer system $50 \mathrm{mM}$ of glycine- $\mathrm{HCl}(\mathrm{pH} 2-4)$, sodium acetate-acetic acid ( $\mathrm{pH} 5-6)$, Tris- $\mathrm{HCl}(\mathrm{pH} 7-9)$, glycine-NaOH $(\mathrm{pH} 10-11)$ and $\mathrm{KCl}-\mathrm{NaOH}(\mathrm{pH} \mathrm{12-13).} \mathrm{The} \mathrm{proteolytic} \mathrm{activity} \mathrm{was} \mathrm{determined} \mathrm{at} \mathrm{each} \mathrm{pH}$ under the optimum temperature. Later, the enzyme solution was mixed with different $\mathrm{pH}$ buffers $(\mathrm{pH} 2-13)$ at $25^{\circ} \mathrm{C}$ for $1 \mathrm{~h}$ to explore the enzyme stability and residual activity at different $\mathrm{pH}$ conditions. The unincubated enzyme activity measured by Tris- $\mathrm{HCl}$ buffer $(\mathrm{pH} 7)$ was considered as $100 \%$.

Effect of $\mathrm{NaCl}$ on enzyme activity and stability

The fermentation supernatant was dialyzed using a dialysis bag (molecular weight cut-off $=8000 \mathrm{Da}$ ) against $50 \mathrm{mM}$ Tris- $\mathrm{HCl} \mathrm{pH} 7$ buffer for $4 \mathrm{~h}$ at $25^{\circ} \mathrm{C}$, and the dialysis buffer was updated hourly to ensure the reliability of the experimental results. Later, the enzyme solution was amended with $\mathrm{NaCl}$ at final concentrations of $0-220 \mathrm{~g} / \mathrm{L}$, and the effect of $\mathrm{NaCl}$ on hydrolytic activity against casein was measured. The salt-containing enzyme solution was preincubated at $25^{\circ} \mathrm{C}$ for $1 \mathrm{~h}$ prior to determination of residual activities to assess its $\mathrm{NaCl}$ stability. The enzyme solution without $\mathrm{NaCl}$ served as the control and was considered as $100 \%$.

Effect of chemical agents on protease activity 
The effect of chemical agents on protease catalysis was investigated by preincubating the crude enzyme at $25^{\circ} \mathrm{C}$ for $1 \mathrm{~h}$ with each reagent. Organic solvents, such as glycerol, methanol, benzene, acetone, ethanol, n-hexane, isopropanol and ethanediol were provided at the working concentrations of 5 and $10 \%$ (v/v), respectively. Similarly, the surfactants, such as Tween 20 , Tween 80 , Triton X-100, dimethyl sulfoxide (DMSO) and $\mathrm{H}_{2} \mathrm{O}_{2}$, were evaluated at $1 \%(\mathrm{v} / \mathrm{v})$. Other classes of chemical agents were used at a final concentration of $5 \mathrm{mM}$; protease inhibitors: phenylmethylsulfonyl fluoride (PMSF), ethylene-diaminetetraacetic acid (EDTA) and ethylene glycol-bis ( $\beta$-aminoethyl ether)-N,N,N',N'-tetraacetic acid (EGTA); reducing agents: dithiothreitol (DTT) and $\beta$-mercaptoethanol ( $\beta-\mathrm{ME})$. The crude enzyme solution incubated in the ultrapure water was used as a control and considered as $100 \%$ enzyme activity.

Effect of different metal ions on protease activity

The effect of different metal ions were determined at $5 \mathrm{mM}$ concentration; monovalent cations: $\mathrm{Li}^{+}, \mathrm{K}^{+}$ and $\mathrm{Ag}^{+}$; divalent cations: $\mathrm{Sr}^{2+}, \mathrm{Mn}^{2+}, \mathrm{Fe}^{2+}, \mathrm{Co}^{2+}, \mathrm{Cu}^{2+}, \mathrm{Zn}^{2+}, \mathrm{Ca}^{2+}, \mathrm{Ba}^{2+}$ and $\mathrm{Mg}^{2+}$; trivalent cations: $\mathrm{Fe}^{3+}$ and $\mathrm{Cr}^{3+}$. The enzyme solution was incubated with the respective metal ion solution at $25^{\circ} \mathrm{C}$ for $1 \mathrm{~h}$, and the residual activity was measured following the optimal conditions. The enzyme solution treated with ultrapure water served as the control.

Substrate specificity

Substrate specificity was determined under standard assay conditions using different protein substrates, including casein, gelatin, collagen, keratin, azocasein and BSA. All the substrates were added to a final concentration of $10 \mathrm{~g} / \mathrm{L}$.

\section{Dehairing performance of 0 . caprae $L 9^{\top}$ protease}

The fresh goatskins, cowhides and rabbit skins were procured from a local farm, and required consent was obtained from the farmer to use these animal parts for experiments. Some pieces of skin with hair were cut with a sharp knife from the same area of the obtained hides, then rinsed with tap water several times and drained at $25^{\circ} \mathrm{C}$. Most hides were independently placed into a flask containing $100 \mathrm{~mL}$ diluted crude enzyme $(600 \mathrm{U})$ and $30 \mathrm{mg} / \mathrm{g} \mathrm{Na}_{2} \mathrm{~S}$, respectively, while the rest of the hides were submerged in 100 $\mathrm{mL}$ of Tris-HCl buffer $(\mathrm{pH} 7)$ containing $20 \mathrm{~g} / \mathrm{L} \mathrm{NaCl}$ that served as a control. All the flasks were incubated in a shaker incubator for $24 \mathrm{~h}$ at $150 \mathrm{rpm}$ and $38^{\circ} \mathrm{C}$. Afterward, the application prospect of crude enzyme in the leather industry was evaluated through dehairing efficacy and histological examination.

About $1 \mathrm{~cm}^{2}$ pelts from the hides treated with Tris-HCl buffer, $\mathrm{Na}_{2} \mathrm{~S}$ and enzyme, were incised and fixed with $40 \mathrm{~g} / \mathrm{L}$ paraformaldehyde (Servicebio, China) for $24 \mathrm{~h}$. The immobilized samples were dehydrated by ethanol, embedded with paraffin wax and cut by microtome. Then the slices were stained by hematoxylin and eosin (HE) and Masson's trichrome staining, and observed using a microscope (Olympus, Japan).

Statistical analysis 
All experiments were performed in triplicate, and the control experiments were proceeded under the identical conditions. The statistical data analysis was done using the software OriginPro version 8.5 , and the results were presented as mean \pm standard deviation (SD).

Nucleotide sequences accession numbers

The 16S rRNA gene sequences and the whole genome of strain $L 9^{\top}$ have been submitted to the GenBank database under accession MN577409 and WOCA00000000, respectively.

\section{Results And Discussion}

\section{Genomic characteristics}

The family Bacillaceae was first proposed by Fischer, and it now includes more than 100 recognized genera (Parte et al. 2020), including Virgibacillus, Oceanobacillus and Ornithinibacillus, the neighbors of the phylogenetic evolution. Additionally, in the phylogenomic tree (Fig. 1), the species of the genera Oceanobacillus and Ornithinibacillus are intertwined with each other, specifying that their genomes have some identical sequences or are highly similar. To date, a few Oceanobacillus species have been isolated and reported to secrete protease ( $\mathrm{Li}$ et al. 2017; Pandey et al. 2012; Thanapun 2013), lipase, amylase and carboxymethyl cellulase (Rohban et al. 2009; Seghal Kiran et al. 2014). Thus, as the twin brother of Oceanobacillus, the Ornithinibacillus species might also have the ability to produce enzymes. A total of 3944 coding DNA sequences of strain $\mathrm{L}^{\top}$ obtained from homology analyses were annotated by the NR database, including at least 25 enzyme-encoding genes. The most abundant was serine protease, followed by metalloprotease, lipase, amylase and glycosidase. The diversity of enzyme genes provides theoretical support for further research on strain $L 9^{\top}$. Furthermore, a zone of clearing formed by strain $L 9^{\top}$ was overtly observed on the milk agar plates, and the protease activity was detected at $60.97 \mathrm{U} / \mathrm{mL}$ in the TSB medium supplemented with $100 \mathrm{~g} / \mathrm{L} \mathrm{NaCl}$.

\section{Statistical optimization of protease production}

\section{Response surface methodology for optimizing experimental design}

The significant independent variables [yeast extract (A), urea (B) and initial $\mathrm{pH}(\mathrm{C})$ ] were used to determine the optimum levels of these parameters based on the single-factor experimental results (depicted in Supplementary Material). The response values of 17 experiments are listed in Table S2. Later, the DesignExport software was employed for regression analysis and significance tests. A quadratic model was generated and applied to predict the maximum protease production $(\mathrm{Y})$. The model was as follows:

$\mathrm{Y}(\mathrm{U} / \mathrm{mL})=246.15-12.97 \mathrm{~A}-32.89 \mathrm{~B}-7.51 \mathrm{C}+0.35 \mathrm{AB}-37.30 \mathrm{AC}-8.68 \mathrm{BC}-42.35 \mathrm{~A}^{2}-68.29 \mathrm{~B}^{2}-77.57 \mathrm{C}^{2}$

As summarized in Table 1, the variance analysis results of the regression model indicated that the model was significant as it was obvious from the high model $F$-value $(=107.4)$ and very low probability value (< 
0.0001 ). Additionally, the model terms of $A, B, C, A C, A^{2}, B^{2}$ and $C^{2}$ were significant ( $p$-value less than 0.05 ), whereas the interaction between urea and yeast extract was not significant ( $p$-value greater than 0.1). This result indicated that the combination of urea and yeast extract had no significant effect on protease production by 0 . caprae L $^{\top}$. The 'lack of fit F-value' of 3.56 implied that the lack of fit was not significant relative to the pure error. Moreover, the good fits were realized, and the variability of most of the test data was explained by the model, with the correlation coefficient $\left(R^{2}\right)$ of $99.28 \%$ and adjusted $R^{2}$ of $98.36 \%$. The adequate precision was $28.942(>4)$, which was desirable, confirming the feasibility of this model to predict protease production by strain $\mathrm{L}^{\top}$.

The interaction effects and optimum values of a combination of the three independent factors for maximum protease production by 0 . caprae $L 9^{\top}$ were represented by three-dimensional response surface graphs and contour plots (Fig. 2). With the increase of yeast extract in the medium, the caseinolytic activity increased first and then decreased (Fig. 2a and 2b). Fig. 2b depicts the shape of the contour to be ellipse, indicating a significant interaction between yeast extract and $\mathrm{pH}$.

\section{Validation of the optimized process conditions}

Based on the regression equation, three repeated verification tests were performed by setting yeast extract, urea and initial pH at the predicted levels of $14.3 \mathrm{~g} / \mathrm{L}, 3.8 \mathrm{~g} / \mathrm{L}$ and 9.0, respectively. The maximum protease activity of $251.12 \mathrm{U} / \mathrm{mL}$ was predicted by the model, which was comparable to the experimental results $(255.86 \pm 0.71 \mathrm{U} / \mathrm{mL})$, confirming the model's authenticity. After RSM optimization, the protease yield of 0 . caprae $L 9^{\top}$ increased by $319.65 \%$ than the unoptimized medium and original fermentation conditions.

\section{Gel electrophoresis and molecular analysis}

The crude extracellular enzyme produced by strain $L 9^{\top}$ was analyzed through SDS-PAGE and zymogram. As depicted in Fig. 3, a single protein band was obtained with the cell-free supernatant, and its proteolytic activity was confirmed by zymogram using casein as a substrate. The molecular weight of $L 9^{\top}$ protease was estimated as $26 \mathrm{kDa}$, which was consistent with some literature reports. Earlier, Deng et al. (2010) reported the characterization of a $28 \mathrm{kDa}$ high-alkaline serine protease from Bacillus sp. B001. Two detergent stable serine proteases named protease BM1 and BM2 with molecular masses of 29 and 15.5 kDa, respectively, were purified from Bacillus mojavensis A21 (Haddar et al. 2009).

The unique protein band was extracted and detected by mass spectrometry. The offline data was analyzed by ProteinPilot, and a total of 27 peptide sequences were obtained. Afterward, the quality control of peptide fragment was performed based on the unused ProtScore $\geq 1.3$, and 9 peptides (Table S3) with the reliability of no less than $95 \%$ were screened out. These peptides exhibited high homology with $S 8$ family serine peptidases, suggesting that the extracellular enzyme of strain $L 9^{\top}$ might belong to serine protease family and provides a direction for further research. 


\section{Biochemical characterization of the protease}

Effect of $\mathrm{pH}$, temperature and $\mathrm{NaCl}$ on enzymatic activity and stability

As depicted in Fig. 4a, the protease was active over a wide range of $\mathrm{pH}(2-13)$ with the nadir activity at $\mathrm{pH}$ 2. More than $80 \%$ of the protease activity was retained at $\mathrm{pH} 3-13$. Besides, the pH stability profile (Fig. 4b) showed that the extracellular protease was highly stable in the $\mathrm{pH}$ range of 3-13. The enzyme remained 57.54 and $88.64 \%$ of its activity at pH 2 and 13 , respectively, after $1 \mathrm{~h}$ incubation at $25^{\circ} \mathrm{C}$. The protease secreted by 0 . caprae $\mathrm{L}^{\top}$ has broader $\mathrm{pH}$ activity and stability than the previously reported proteases (Ibrahim et al. 2015; Deng et al. 2010). Herein, the protease exhibited a typical characteristic of the serine protease (wider $\mathrm{pH}$ action), suggesting it to be a good candidate for industrial applications such as use in the detergents (Ibrahim et al. 2015), tanning processes (Kanagaraj et al. 2015) or biocontrol agent (Darwesh et al. 2020).

The proteolytic activity was detected at all test temperatures ( 30 to $80^{\circ} \mathrm{C}$ ), and the maximum activity was observed at $70^{\circ} \mathrm{C}$ (Fig. 4c), revealing the thermophilic nature of the protease. The crude protease showed only $5.4 \%$ of the maximal activity at $30^{\circ} \mathrm{C}$ and exhibited a few activities till the enzyme assay at $80^{\circ} \mathrm{C}$. These results were consistent with several studies, including an alkaline serine protease produced by $N$. dassonvillei OK-18 (Sharma et al. 2020), showing the maximal activity at $70^{\circ} \mathrm{C}$, and protease BM2 secreted by B. mojavensis A21 (Haddar et al. 2009), showing the maximal activity at $60^{\circ} \mathrm{C}$. Thermostability studies have revealed that $L 9^{\top}$ protease is quite stable between 30 to $45^{\circ} \mathrm{C}$, retaining 95.75 and $9.02 \%$ of the initial activity after $1 \mathrm{~h}$ of incubation at 50 and $65^{\circ} \mathrm{C}$ (Fig. $4 \mathrm{~d}$ ), respectively. Nevertheless, at $70-80^{\circ} \mathrm{C}$, the enzyme fully denatured and lost activity within $60 \mathrm{~min}$.

The effects of $\mathrm{NaCl}$ on enzyme activities towards casein were determined in the salinity ranging from $0-$ $220 \mathrm{~g} / \mathrm{L}$ at $70^{\circ} \mathrm{C}$. The protease exhibited the optimum activity at $20 \mathrm{~g} / \mathrm{L} \mathrm{NaCl}$ (Fig. 5). The protease retained $80.31,55.23$ and $32.49 \%$ of its activity at $\mathrm{NaCl}$ concentrations of 80,140 and $220 \mathrm{~g} / \mathrm{L}$, respectively, suggesting that high salt concentration suppresses the enzyme activity. Notably, the proteolytic activity measured at different salt concentrations remained unchanged before and after heat preservation, indicating the stability of this protease at all tested $\mathrm{NaCl}$ concentrations for $1 \mathrm{~h}$. These results were in accordance with the recent report of alkaline serine protease from Bacillus sp. NPST-AK15 (Ibrahim et al. 2015), showing the maximum activity at $15 \mathrm{~g} / \mathrm{L} \mathrm{NaCl}$ and highly stability in $\mathrm{NaCl}$ up to 200 $\mathrm{g} / \mathrm{L}$. These findings demonstrate that $L 9^{\top}$ protease is a slightly halophilic enzyme (different from extreme halophilic protease), which could be useful for certain biotechnological processes depending on salinity.

Effect of various metal ions on protease activity

Table 2 summarizes the proteolytic activity of the crude enzyme under incubation with different metal ions. $\mathrm{Ag}^{+}, \mathrm{Ca}^{2+}$ and $\mathrm{Sr}^{2+}$ significantly enhanced the enzyme activities at a rate of $104.46,104.40$ and $120.37 \%$ than the control at a final concentration of $5 \mathrm{mM}$. In consistent with the present study, many investigators have reported the stimulating effect of $\mathrm{Ca}^{2+}$ on serine proteases (Ben Elhoul et al. 2015; 
Jagadeesan et al. 2020; Jaouadi et al. 2013). Gong et al. (2015) has reported that $\mathrm{Sr}^{2+}$ increased the keratinase activity by $10 \%$. The above-mentioned results suggest that $\mathrm{Ag}^{+}, \mathrm{Ca}^{2+}$ and $\mathrm{Sr}^{2+}$ could maintain the stability of the active site of $L 9^{\top}$ protease, which has a selective preference $\mathrm{for}^{2+}{ }^{2+}$ ions at a certain concentration as an inducer. The addition of $\mathrm{Li}^{+}, \mathrm{K}^{+}, \mathrm{Ba}^{2+}, \mathrm{Mg}^{2+}, \mathrm{Mn}^{2+}$ and $\mathrm{Co}^{2+}$ had a little effect on the enzyme activities. Other ions, including $\mathrm{Fe}^{2+}, \mathrm{Fe}^{3+}, \mathrm{Cu}^{2+}$ and $\mathrm{Zn}^{2+}$, significantly inhibited the enzyme activities, and a loss of $70 \%$ in the activity was observed with $\mathrm{Fe}^{3+}$. Moreover, under the same conditions, $\mathrm{Fe}^{3+}$ ions are more likely to deactivate enzyme than $\mathrm{Fe}^{2+}$, which is presumably attributed to the fact that $\mathrm{Fe}^{3+}$ easily absorbs electrons from the enzyme surface through strong oxidation, thereby destroying the enzyme stability. Herein, the enzyme was moderately affected by $\mathrm{Cr}^{3+}$ at $5 \mathrm{mM}$, revealing that the protease might act as an adjuvant to the chrome tannage and bating processes in leather industry.

Effect of chemical substances on protease activity

The effects of various organic solvents on protease were appraised to examine the potential application. Results showed that the crude enzyme was considerably stable in the presence of the tested solvents (Table 3), particularly at a concentration of $5 \%(\mathrm{v} / \mathrm{v})$. Upon incubation with $10 \%(\mathrm{v} / \mathrm{v})$ of glycerol, benzene and $\mathrm{n}$-hexane for $1 \mathrm{~h}$, the enzyme also displayed high stability, with respective residual activity of 99.50 , 100.76 and $95.70 \%$. This remarkable stability exhibited by $L 9^{\top}$ protease in common organic solvents supported the potential candidacy of it as a biocatalyst for the synthesis of peptide and ester.

Later, the effects of surfactants on the extracellular protease were evaluated, and the corresponding results are presented in Table 4. The stimulatory effects were observed in the presence of some nonionic surfactants, such as Tween 20 (163.41\%) and Tween 80 (115.01\%), which were higher than previous reports (Jagadeesan et al. 2020; Ibrahim et al. 2015). On the contrary, the inhibitory effect of Triton X-100 was observed at a concentration of $1 \%(\mathrm{v} / \mathrm{v})$. The enhanced activity of the enzyme in presence of DMSO reflect the fact that DMSO is an amphipathic molecule that easily penetrates the enzyme with low toxicity, and $99.94 \%$ of the activity was maintained (data not shown) at $10 \%$ concentration. The strong anionic surfactant sodium dodecyl sulfate (SDS) at $10 \mathrm{~g} / \mathrm{L}$ inhibited the protease activity up to $76.98 \%$, which was consistent with most of the previous conclusions reporting that SDS denatures and inactivates the enzyme (Ibrahim et al. 2015; Suwannaphan et al. 2017). Furthermore, the $\mathrm{L}^{\top}$ protease was moderately stable against $\mathrm{H}_{2} \mathrm{O}_{2}$, retaining $88.18 \%$ of its initial activity at a concentration of $1 \%$. All these prominent features ensure that the enzyme is compatible with certain detergent formulations.

Moreover, the effect of various inhibitors and chelators on $L 9^{\top}$ protease activity was examined (Table 4). The protease remained unstimulated against thiol reagents, such as DTT and $\beta$-ME at a concentration of $5 \mathrm{mM}$, suggesting that $\mathrm{L} 9^{\top}$ protease is a thiol-independent enzyme, and the thiol group does not directly participate in the catalytic reaction (Ben Elhoul et al. 2016). On the contrary, the protease activity was partially inhibited by the chelators EDTA and EGTA, which confirmed that $L 9^{\top}$ protease is not a member of the metalloprotease family but uses certain cations as stabilizers (Deng et al. 2010; Jellouli et al. 2009). 
Notably, $L 9^{\top}$ protease showed no activity in the presence of $5 \mathrm{mM} \mathrm{PMSF}$, confirming the enzyme to be a serine protease (Jagadeesan et al. 2020).

Substrate specificity profile of the $L 9^{\top}$ protease

The effect of various substrates on $L 9^{\top}$ protease activity is summarized in Fig. S4. The highest activity was observed against casein, but a relatively high activity was observed against azocasein. However, no activity was observed toward gelatin, collagen and keratin. Therefore, the absence of collagenase activity indicates the potential application of $\mathrm{Lg}^{\top}$ protease in hair removal in the leather industry without damaging the skin collagen.

\section{Hide dehairing ability of the crude enzyme}

The dehairing efficacy of the crude enzyme from 0 . caprae $L 9^{\top}$ on hides was evaluated by touch-visual tests and histological analyses. The pelt with hair, traditional dehaired pelt, and enzymatic dehaired hide are depicted in Fig. 6 . The results elucidated that both the traditional sodium sulfide depilation and enzymatic dehairing could effectively remove the hair from goatskins, cowhides and rabbit skins; however, the control hides, incubated under the same conditions, showed no sign of hair removal. Notably, the enzymatic dehaired pelts were white in color and displayed smooth grain surface, soft touch and clean hair pores; while, organoleptic tests showed that the skins obtained after chemical dehairing were dark brown or yellow in color, wrinkled and hard in touch. Sodium sulfide dissolved in water could produce large amounts of hydroxide, and the disulfide bond of the hair breaks under the action of strong alkali to complete the hair removal process (Sujitha et al. 2018), which leads to the production of toxic gas $\mathrm{H}_{2} \mathrm{~S}$. In contrast, as a biologically active catalyst, the crude enzyme cannot directly act on hair shafts; instead, it may hydrolyze the mucinoid, mucin, albumin and globulin in raw skin tissue, thereby destroying the bond between the hair follicle and the hair root, the hair bulb and the hair papilla, to achieve the purpose of hair removal (Sujitha et al. 2018; Yates 1972).

The histological images of control, $\mathrm{Na}_{2} \mathrm{~S}$ and crude enzyme treated goatskins stained with $\mathrm{HE}$ and Masson's trichrome staining are depicted in Fig. S5. The results demonstrated that compared with the blank control, the epidermis was removed from the goatskins via two different treatments; and the collagen fiber structure of the enzymatically dehaired pelt was more regular and intact compared with the $\mathrm{Na}_{2} \mathrm{~S}$ treatment. It could be observed from Masson's trichrome staining images that the collagen components appeared in blue color, and the non-collagen substances appeared in deep red color. This result suggested that the enzyme treatment could well maintain the inherent collagen component in the dermal structure, while part of the damaged collagen existed in the fur treated with $\mathrm{Na}_{2} \mathrm{~S}$. Overall, the crude enzyme exhibited no collagenase activity, and was advantageous over chemical depilatory agents.

In this study, the crude protease completely dehaired the skins from goat and rabbit (Fig. 6a and 6c) in 24 $\mathrm{h}$ without any chemicals. This result strengthened the hypothesis that this protease could be beneficial to protect the environment and reduce energy waste (Jaouadi et al. 2013; Kandasamy et al. 2012). 
Moreover, the reasons for incomplete enzymatic depilation of cowhide (Fig. 6b) might be attributed to the fact that the thick cowhide leads to slower enzyme penetration and lack of mechanical pulling force. It is noteworthy to mention that the microbial enzymes with excellent dehairing ability are stable in an alkaline environment, especially between pH 8 and 10 (Jaouadi et al. 2013; Bouacem et al. 2016). Fortunately, L9 ${ }^{\top}$ protease meets these criteria and hence, is considered as a potential dehairing candidate in improving leather quality.

\section{Conclusions}

In the present study, a novel thermophilic and slightly halophilic serine protease from 0 . caprae $L 9^{\top}$ was reported. The halophile exhibited a higher protease production capacity $(255.86 \mathrm{U} / \mathrm{mL})$ under the following conditions: $72 \mathrm{~h}$ of fermentation time, initial $\mathrm{pH}$ 9, culture temperature $37^{\circ} \mathrm{C}$, and the modified medium containing $14.3 \mathrm{~g}$ yeast extract, $3.8 \mathrm{~g}$ urea, $130 \mathrm{~g} \mathrm{NaCl}$ and $1 \mathrm{~L}$ distilled water. The crude enzyme appeared as a single band on SDS-PAGE with a molecular mass of $26 \mathrm{kDa}$. The optimum temperature for caseinolytic activity was $70^{\circ} \mathrm{C}$. Furthermore, the protease activity was enhanced by metal ions $\mathrm{Ca}^{2+}, \mathrm{Sr}^{2+}$, $\mathrm{Ag}^{+}$and $20 \mathrm{~g} / \mathrm{L} \mathrm{NaCl}$. The enzyme exhibited excellent stability toward surfactants, organic solvents and a wide range of $\mathrm{pH}$ from 3 to 13 . Further studies confirmed that the crude protease has an excellent ability to remove hair in a short time without damaging the collagen. In summary, the protease could be a propitious candidate for various industrial applications.

\section{Declarations}

Acknowledgement This work was supported by the National Key Research and Development Program of China (2017YFB0308401).

Author contributions XL performed the experiment and wrote the manuscript. QZ revised the grammar and typography of the manuscript. LG and GJ provided guidance on response surface analyses. YT supervised and guided the experiments. BS critically reviewed the structure of manuscript.

\section{Compliance with ethical standards}

Conflicts of interest The authors declare that there are no conflicts of interest.

Ethical statement This article does not contain any studies with human participants and/or animals performed by any of the authors.

\section{References}

1. Barzkar N (2020) Marine microbial alkaline protease: An efficient and essential tool for various industrial applications. Int J Biol Macromol 161:1216-1229 
2. Ben Elhoul M, Zarai Jaouadi N, Rekik H, Bejar W, Boulkour Touioui S, Hmidi M, Badis A, Bejar S, Jaouadi B (2015) A novel detergent-stable solvent-tolerant serine thiol alkaline protease from Streptomyces koyangensis TN650. Int J Biol Macromol 79:871-882

3. Ben Elhoul M, Zarai Jaouadi N, Rekik H, Omrane Benmrad M, Mechri S, Moujehed E, Kourdali S, El Hattab M, Badis A, Bejar S, Jaouadi B (2016) Biochemical and molecular characterization of new keratinoytic protease from Actinomadura viridilutea DZ50. Int J Biol Macromol 92:299-315

4. Bouacem K, Bouanane-Darenfed A, Zarai Jaouadi N, Joseph M, Hacene H, Ollivier B, Fardeau ML, Bejar S, Jaouadi B (2016) Novel serine keratinase from Caldicoprobacter algeriensis exhibiting outstanding hide dehairing abilities. Int J Biol Macromol 86:321-328

5. Brandelli A (2007) Bacterial Keratinases: Useful Enzymes for Bioprocessing Agroindustrial Wastes and Beyond. Food Bioprocess Tech 1:105-116

6. Chandrasekaran M, Chandrasekar R, Chun SC, Sathiyabama M (2016) Isolation, characterization and molecular three-dimensional structural predictions of metalloprotease from a phytopathogenic fungus, Alternaria solani (Ell and Mart) Sor. J Biosci Bioeng 122:131-139

7. Darwesh OM, Ali SS, Matter IA, Elsamahy T, Mahmoud YA (2020) Enzymes immobilization onto magnetic nanoparticles to improve industrial and environmental applications. Meth Enzymol 630:481-502

8. Deng A, Wu J, Zhang Y, Zhang G, Wen T (2010) Purification and characterization of a surfactantstable high-alkaline protease from Bacillus sp B001. Bioresour Technol 101:7111-7117

9. Dettmer A, Cavalli É, Ayub MAZ, Gutterres M (2013) Environmentally friendly hide unhairing: enzymatic hide processing for the replacement of sodium sulfide and delimig. J Clean Prod 47:1118

10. Garciacarreno FL, Dimes LE, Haard NF (1993) Substrate Gel-Electrophoresis for Composition and Molecular-Weight of Proteinases of Proteinaceous Proteinase-Inhibitors. Anal Biochem 214:65-69

11. Gong JS, Wang Y, Zhang DD, Zhang RX, Su C, Li H, Zhang XM, Xu ZH, Shi JS (2015) Biochemical characterization of an extreme alkaline and surfactant-stable keratinase derived from a newly isolated actinomycete Streptomyces aureofaciens K13. Rsc Adv 5:24691-24699

12. Gradisar H, Friedrich J, Krizaj I, Jerala R (2005) Similarities and specificities of fungal keratinolytic proteases: comparison of keratinases of Paecilomyces marquandii and Doratomyces microsporus to some known proteases. Appl Environ Microbiol 71:3420-3426

13. Haddar A, Agrebi R, Bougatef A, Hmidet N, Sellami-Kamoun A, Nasri M (2009) Two detergent stable alkaline serine-proteases from Bacillus mojavensis A21: purification, characterization and potential application as a laundry detergent additive. Bioresour Technol 100:3366-3373

14. Ibrahim ASS, Al-Salamah AA, El-Badawi YB, El-Tayeb MA, Antranikian G (2015) Detergent-, solventand salt-compatible thermoactive alkaline serine protease from halotolerant alkaliphilic Bacillus $\mathrm{sp}$ NPST-AK15: purification and characterization. Extremophiles 19:961-971

15. Jagadeesan Y, Meenakshisundaram S, Saravanan V, Balaiah A (2020) Sustainable production, biochemical and molecular characterization of thermo-and-solvent stable alkaline serine keratinase 
from novel Bacillus pumilus AR57 for promising poultry solid waste management. Int J Biol Macromol 163:135-146

16. Jaouadi NZ, Rekik H, Badis A, Trabelsi S, Belhoul M, Yahiaoui AB, Ben Aicha H, Toumi A, Bejar S, Jaouadi B (2013) Biochemical and molecular characterization of a serine keratinase from Brevibacillus brevis US575 with promising keratin-biodegradation and hide-dehairing activities. PLoS One 8:e76722

17. Jellouli K, Bougatef A, Manni L, Agrebi R, Siala R, Younes I, Nasri M (2009) Molecular and biochemical characterization of an extracellular serine-protease from Vibrio metschnikovii J1. J Ind Microbiol Biotechnol 36:939-948

18. Kanagaraj J, Senthilvelan T, Panda RC, Kavitha S (2015) Eco-friendly waste management strategies for greener environment towards sustainable development in leather industry: a comprehensive review. J Clean Prod 89:1-17

19. Kandasamy N, Velmurugan P, Sundarvel A, Rao JR, Bangaru C, Palanisamy T (2012) Eco-benign enzymatic dehairing of goatskins utilizing a protease from a Pseudomonas fluorescens species isolated from fish visceral waste. J Clean Prod 25:27-33

20. Kostyleva EV, Sereda AS, Velikoretskaya IA, Nefedova LI, Sharikov AY, Tsurikova NV, Lobanov NS, Semenova MV, Sinitsyn AP (2016) A new Bacillus licheniformis mutant strain producing serine protease efficient for hydrolysis of soy meal proteins. Microbiology 85:462-470

21. Laemmli UK (1970) Cleavage of structure protein during the assembly of the head of bacteriophage T4. Nature 227:680-685

22. Li W, Jaroszewski L, Godzik A (2002) Tolerating some redundancy significantly speeds up clustering of large protein databases. Bioinformatics 18:77-82

23. Li X, Zhang S, Gan L, Cai C, Tian Y, Shi B (2020) Ornithinibacillus caprae sp nov, a moderate halophile isolated from the hides of a white goat. Arch Microbiol 202:1469-1476

24. Li Y, Wu C, Zhou M, Wang ET, Zhang Z, Liu W, Ning J, Xie Z (2017) Diversity of Cultivable ProteaseProducing Bacteria in Laizhou Bay Sediments, Bohai Sea, China. Front Microbiol 8:405

25. Meier-Kolthoff JP, Goker M (2019) TYGS is an automated high-throughput platform for state-of-theart genome-based taxonomy. Nat Commun 10:2182

26. Ockerman HW, Basu L (2014) BY-PRODUCTS I Hides and Skins, in: Dikeman, M, Devine, C (Eds), Encyclopedia of Meat Sciences (Second Edition) Academic Press, Oxford, pp 112-124

27. Pandey S, Rakholiya KD, Raval VH, Singh SP (2012) Catalysis and stability of an alkaline protease from a haloalkaliphilic bacterium under non-aqueous conditions as a function of $\mathrm{pH}$, salt and temperature. J Biosci Bioeng 114:251-256

28. Parte AC, Sarda Carbasse J, Meier-Kolthoff JP, Reimer LC, Goker M (2020) List of Prokaryotic names with Standing in Nomenclature (LPSN) moves to the DSMZ. Int J Syst Evol Microbiol 70:5607-5612

29. Paul T, Jana A, Mandal AK, Mandal A, Das Mohpatra PK, Mondal KC (2016) Bacterial keratinolytic protease, imminent starter for NextGen leather and detergent industries. Sustain Chem Pharm 3:822

Page 14/ 25 
30. Rohban R, Amoozegar MA, Ventosa A (2009) Screening and isolation of halophilic bacteria producing extracellular hydrolyses from Howz Soltan Lake, Iran. J Ind Microbiol Biotechnol 36:333340

31. Seghal Kiran G, Nishanth Lipton A, Kennedy J, Dobson AD, Selvin J (2014) A halotolerant thermostable lipase from the marine bacterium Oceanobacillus sp PUMB02 with an ability to disrupt bacterial biofilms. Bioengineered 5:305-318

32. Sharma AK, Kikani BA, Singh SP (2020) Biochemical, thermodynamic and structural characteristics of a biotechnologically compatible alkaline protease from a haloalkaliphilic, Nocardiopsis dassonvillei OK-18. Int J Biol Macromol 153:680-696

33. Sujitha P, Kavitha S, Shakilanishi S, Babu NKC, Shanthi C (2018) Enzymatic dehairing: a comprehensive review on the mechanistic aspects with emphasis on enzyme specificity. Int J Biol Macromol 118:168-179

34. Sun F, Sun Q, Zhang H, Kong B, Xia X (2019) Purification and biochemical characteristics of the microbial extracellular protease from Lactobacillus curvatus isolated from Harbin dry sausages. Int $\mathrm{J}$ Biol Macromol 133:987-997

35. Suwannaphan S, Fufeungsombut E, Promboon A, Chim-anage P (2017) A serine protease from newly isolated Bacillus sp for efficient silk degumming, sericin degrading and colour bleaching activities. Int Biodeter Biodegr 117:141-149

36. Thanapun T (2013) Screening and characterization of protease-producing Virgibacillus, Halobacillus and Oceanobacillus strains from Thai fermented fish. J App Pharm Sci 3:025-030

37. Thanikaivelan P, Rao JR, Nair BU, Ramasami T (2004) Progress and recent trends in biotechnological methods for leather processing. Trends Biotechnol 22:181-188

38. Wang R, Min C, Haiming C, Li ZQ (2009) Enzyme unhairing- an eco-friendly process. J Soc Leath Tech Ch 93:51-55

39. Wang SL, Hsu WT, Liang TW, Yen YH, Wang CL (2008) Purification and characterization of three novel keratinolytic metalloproteases produced by Chryseobacterium indologenes TKU014 in a shrimp shell powder medium. Bioresour Technol 99:5679-5686

40. Ward OP (2011) Proteases, in: M. Moo-Young (Ed.), Comprehensive Biotechnology (Second Edition), Academic Press, Burlington, pp 571-582

41. Yates JR (1972) Studies in depilation. Part X. The mechanism of the enzyme depilation process. J Soc Leather Trades Chem 56:158-177

\section{Tables}

Table 1. Analysis of variance for the regression equation 


\begin{tabular}{|llllll|}
\hline Source & Sum of squares & $\mathrm{df}$ & Mean squares & F-value & $p$-value \\
\hline Model & 74551.59 & 9 & 8283.51 & 107.40 & $<0.0001^{\star *}$ \\
\hline A-Yeast extract & 1346.02 & 1 & 1346.02 & 17.45 & $0.0042^{\star *}$ \\
\hline B-Urea & 8652.39 & 1 & 8652.39 & 112.18 & $<0.0001^{\star *}$ \\
\hline C-pH & 451.79 & 1 & 451.79 & 5.86 & $0.0461^{\star}$ \\
\hline AB & 0.48 & 1 & 0.48 & 0.01 & $0.9392 \dagger$ \\
\hline AC & 5565.63 & 1 & 5565.63 & 72.16 & $<0.0001^{\star *}$ \\
\hline BC & 301.41 & 1 & 301.41 & 3.91 & 0.0886 \\
\hline A & 7552.10 & 1 & 7552.10 & 97.91 & $<0.0001^{\star *}$ \\
\hline B & 19637.99 & 1 & 19637.99 & 254.61 & $<0.0001^{\star *}$ \\
\hline$C^{2}$ & 25334.82 & 1 & 25334.82 & 328.47 & $<0.0001^{\star *}$ \\
\hline Residual & 539.90 & 7 & 77.13 & & \\
\hline Lack of fit & 392.94 & 3 & 130.98 & 3.56 & $0.1256 \dagger$ \\
\hline Pure error & 146.97 & 4 & 36.74 & & \\
\hline Cor total & 75091.49 & 16 & & & \\
\hline
\end{tabular}

F, F ratio; $p$-value, probability value; df, degree of freedom.

*, Significant $(p<0.05) ;{ }^{*}$, very significant $(p<0.01) ;$, not significant $(p>0.1)$.

$\mathrm{R}^{2}=0.9928 ;$ adjusted $\mathrm{R}^{2}=0.9836 ;$ adequate precision $=28.942$.

Table 2. Effect of different metal ions on the protease activity 


\begin{tabular}{|lll|}
\hline Metal ions & Final Concentration $(\mathrm{mM})$ & Relative activity $( \pm \mathrm{SD})(\%)$ \\
\hline Control & - & $100.00 \pm 0.79$ \\
\hline $\mathrm{Li}^{+}$ & 5 & $90.19 \pm 0.97$ \\
\hline $\mathrm{K}^{+}$ & 5 & $97.71 \pm 2.49$ \\
\hline $\mathrm{Ag}^{+}$ & 5 & $104.46 \pm 1.27$ \\
\hline $\mathrm{Fe}^{2+}$ & 5 & $84.85 \pm 1.25$ \\
\hline $\mathrm{Cu}^{2+}$ & 5 & $85.32 \pm 1.40$ \\
\hline $\mathrm{Zn}^{2+}$ & 5 & $78.39 \pm 2.47$ \\
\hline $\mathrm{Ca}^{2+}$ & 5 & $104.40 \pm 2.12$ \\
\hline $\mathrm{Mg}^{2+}$ & 5 & $97.77 \pm 2.00$ \\
\hline $\mathrm{Ba}^{2+}$ & 5 & $93.31 \pm 2.92$ \\
\hline $\mathrm{Mn}^{2+}$ & 5 & $96.36 \pm 2.13$ \\
\hline $\mathrm{Co}^{2+}$ & 5 & $95.54 \pm 0.35$ \\
\hline $\mathrm{Sr}^{2+}$ & 5 & $120.37 \pm 3.10$ \\
\hline $\mathrm{Fe}^{3+}$ & 5 & $28.55 \pm 3.16$ \\
\hline $\mathrm{Cr}^{3+}$ & 5 & $84.15 \pm 1.64$ \\
\hline
\end{tabular}

Table 3. Effect of organic solvents on $\mathrm{L} 9^{\top}$ protease stability 


\begin{tabular}{|lll|}
\hline Solvents & \multicolumn{2}{l|}{ Relative activity $( \pm \mathrm{SD})(\%)$} \\
\cline { 2 - 3 } & $5 \%(\mathrm{v} / \mathrm{v})$ & $10 \%(\mathrm{v} / \mathrm{v})$ \\
\hline Control & $100.00 \pm 0.1$ & - \\
\hline Acetone & $88.44 \pm 5.31$ & $85.09 \pm 3.72$ \\
\hline Benzene & $100.76 \pm 2.24$ & $95.83 \pm 6.36$ \\
\hline Ethanediol & $99.12 \pm 2.28$ & $93.37 \pm 2.10$ \\
\hline Ethanol & $90.90 \pm 0.77$ & $74.92 \pm 4.05$ \\
\hline Glycerol & $88.76 \pm 3.03$ & $99.50 \pm 1.22$ \\
\hline n-Hexane & $91.16 \pm 1.91$ & $95.70 \pm 3.94$ \\
\hline Isopropanol & $91.98 \pm 1.37$ & $71.64 \pm 4.18$ \\
\hline Methanol & $97.22 \pm 3.90$ & $89.77 \pm 2.22$ \\
\hline
\end{tabular}

Table 4. Effect of various surfactants, oxidizing agent, alkahest and inhibitors on crude serine protease from O. caprae $L 9^{\top}$ 


\begin{tabular}{|lll|}
\hline Chemical substances & Working concentration & Relative activity $( \pm$ SD) $(\%)$ \\
\hline Control & - & $100.00 \pm 3.06$ \\
\hline Surfactants & \\
\hline Tween 20 & $1 \%(\mathrm{v} / \mathrm{v})$ & $163.41 \pm 2.23$ \\
\hline Tween 80 & $1 \%(\mathrm{v} / \mathrm{v})$ & $115.01 \pm 1.13$ \\
\hline Triton X-100 & $1 \%(\mathrm{v} / \mathrm{v})$ & $90.34 \pm 3.32$ \\
\hline SDS & $10 \mathrm{~g} / \mathrm{L}$ & $23.02 \pm 1.18$ \\
\hline Oxidizing agent & & \\
\hline $\mathrm{H}_{2} \mathrm{O}_{2}$ & $1 \%(\mathrm{v} / \mathrm{v})$ & $88.18 \pm 1.18$ \\
\hline Alkahest & & \\
\hline DMSO & $1 \%(\mathrm{v} / \mathrm{v})$ & $110.22 \pm 1.70$ \\
\hline Inhibitors & & $96.96 \pm 0.73$ \\
\hline DTT & $5 \mathrm{mM}$ & $95.05 \pm 2.23$ \\
\hline$\beta$-Me & $5 \mathrm{mM}$ & $30.44 \pm 2.77$ \\
\hline EDTA & $5 \mathrm{mM}$ & $49.85 \pm 0.60$ \\
\hline EGTA & $5 \mathrm{mM}$ & 0 \\
\hline PMSF & $5 \mathrm{mM}$ & \\
\hline
\end{tabular}

Figures 


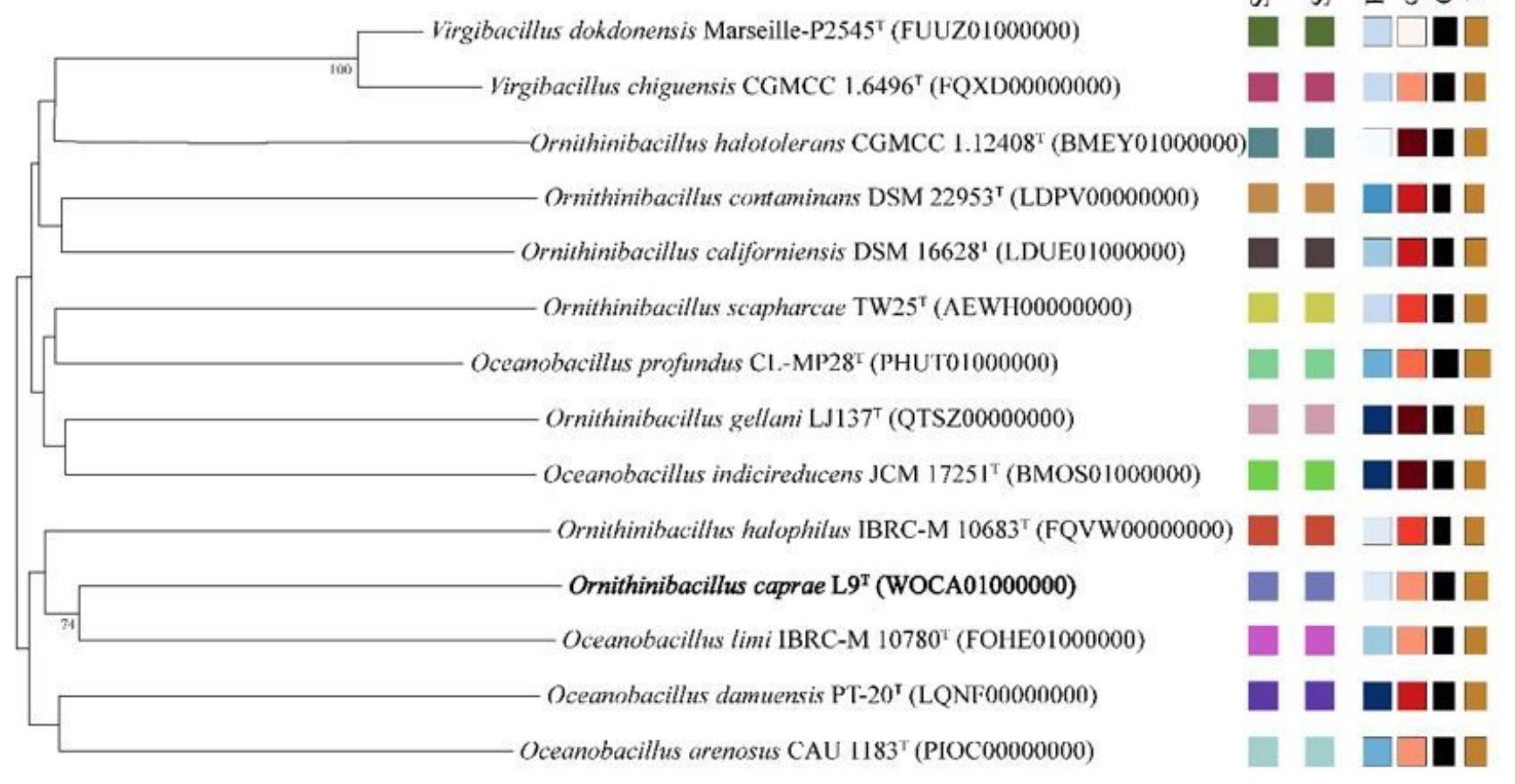

\section{Figure 1}

The phylogenomic tree based on genome sequences of O. caprae L9T and the related type species using the genome blast distance phylogeny (GBDP) method. The numbers above branches are GBDP pseudobootstrap support values $>70 \%$ from 100 replications. 

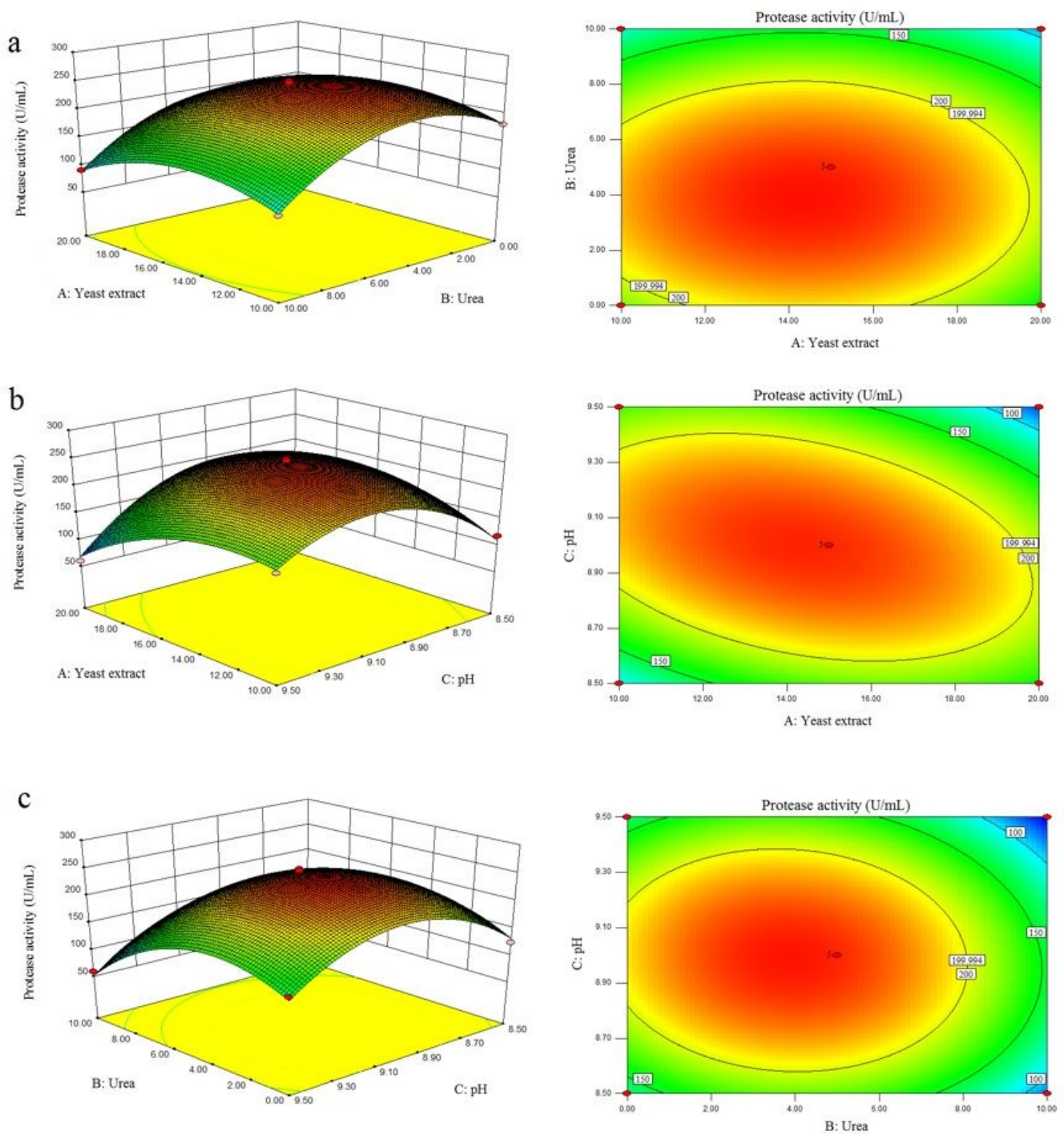

\section{Figure 2}

Three-dimensional response surface graphs and contour plots of extracellular protease production by 0 . caprae L9T elucidating the interaction between: a, yeast extract and urea; $b$, yeast extract and $\mathrm{pH} ; \mathrm{c}$, urea and $\mathrm{pH}$. 


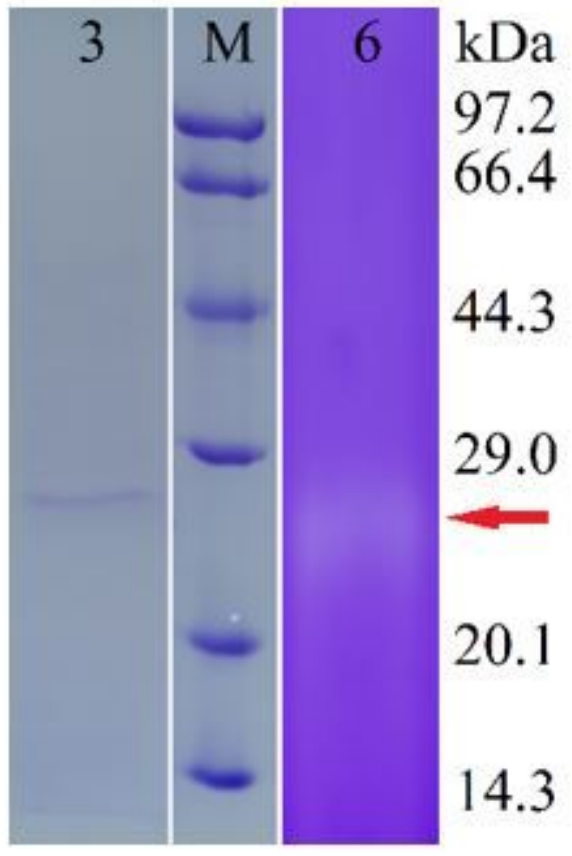

Figure 3

SDS-PAGE (12.5\%) of extracellular protease from 0. caprae L9T. Lane 3, cell-free supernatant; lane M, molecular weight marker; lane 6, crude enzyme zymogram. 

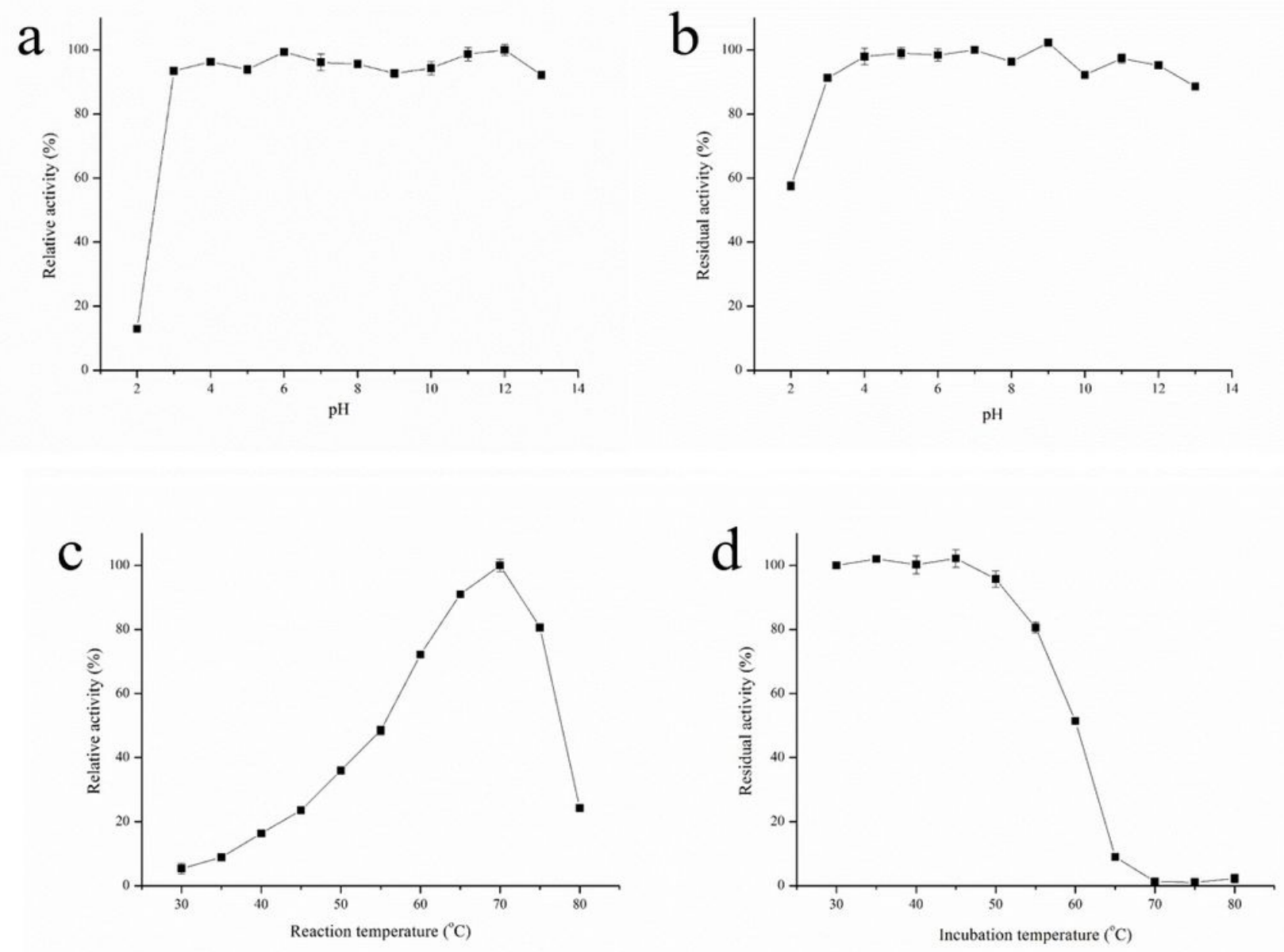

\section{Figure 4}

Effect of $\mathrm{pH}$ and temperature on the protease activities from 0. caprae L9T. a, Relative activities at different $\mathrm{pH}$ values; $\mathrm{b}, \mathrm{pH}$ stability of the protease; $\mathrm{c}$, relative activities at different temperatures; $d$, thermal stability of the protease. Results represent means of three experiments, and vertical bars indicate standard error of the mean. 


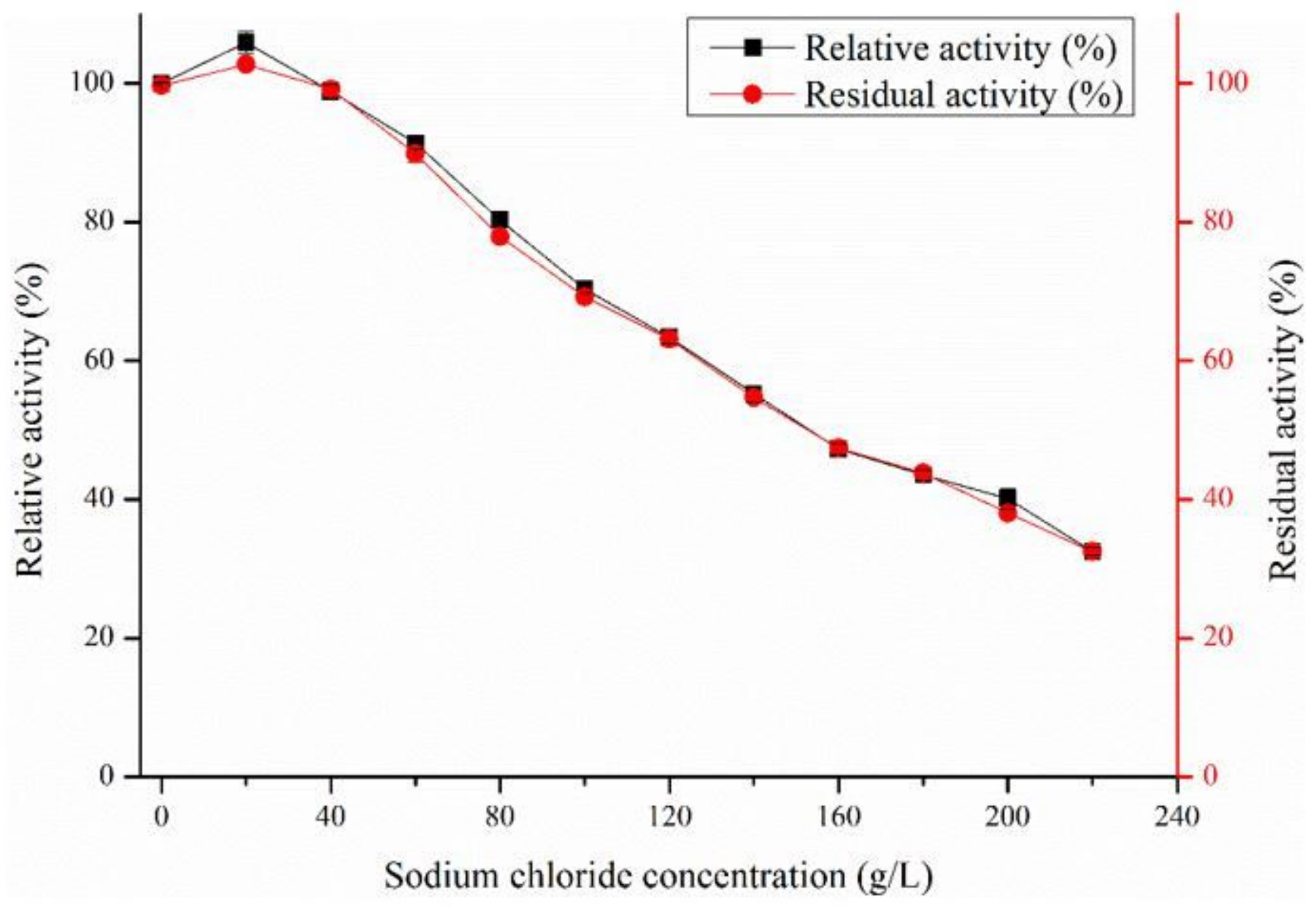

Figure 5

Effect of various concentrations of $\mathrm{NaCl}(0-220 \mathrm{~g} / \mathrm{L})$ on activity and stability of the dialysed L9T protease. Each value represents mean $\pm S D, n=3$. 

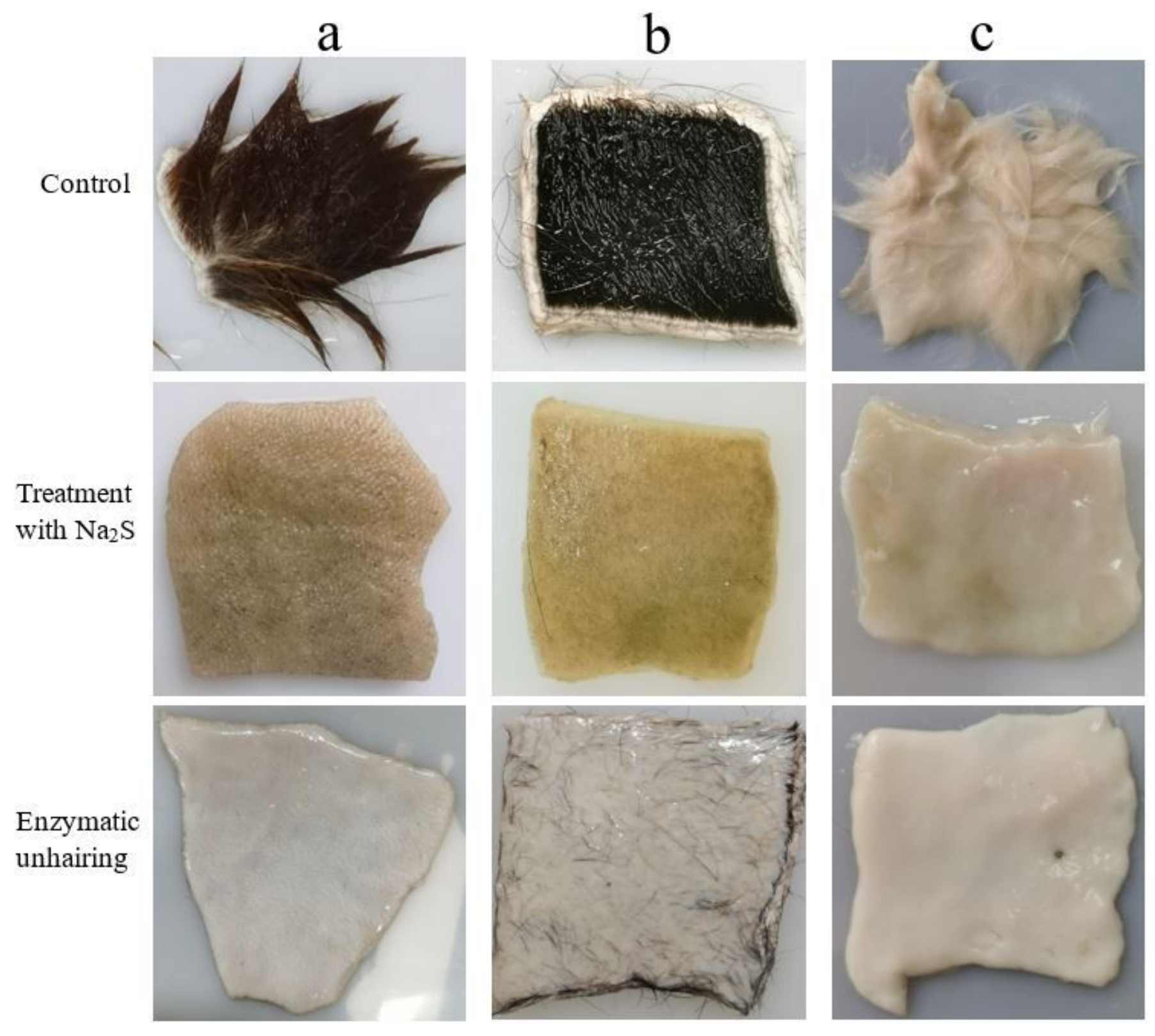

\section{Figure 6}

Dehairing performance on goatskin (a), cowhide (b) and rabbit skin (c) of crude enzyme from 0. caprae L9T.

\section{Supplementary Files}

This is a list of supplementary files associated with this preprint. Click to download.

- CertificateofEnglishEditing.pdf

- SupplementaryMaterial.pdf 